\title{
Technologia cyfrowa \\ w muzeach narracyjnych na przykładzie Muzeum Powstania Warszawskiego i Muzeum Historii Żydów Polskich POLIN ${ }^{1}$
}

\author{
Teresa Zachara \\ Ministerstwo Kultury i Dziedzictwa Narodowego
}

\begin{abstract}
Abstrakt
Cel/Teza: Artykuł przedstawia wyniki badań, których celem było ustalenie zakresu i sposobów wykorzystywania technologii cyfrowej przez dwa znane polskie muzea narracyjne: Muzeum Powstania Warszawskiego (MPW) i Muzeum Historii Żydów Polskich POLIN (Muzeum POLIN).

Koncepcja/Metody badań: W przedstawionych studiach wykorzystano trzy techniki badawcze: analizę źródeł, która pozwoliła na zorientowanie się w zmieniającej się roli muzeów oraz wykorzystywanie przez te placówki technologii cyfrowej; wizję lokalną i wywiad z pracownikami Muzeum Powstania Warszawskiego i Muzeum Historii Żydów Polskich POLIN, które pozwoliły na zapoznanie się z zastosowanymi w tych placówkach elementami technologii cyfrowej; analizę stron internetowych wspomnianych dwóch muzeów. Triangulacja tych technik umożliwiła przedstawienie systematycznego przeglądu zastosowań różnych narzędzi i metod technologii cyfrowej w różnych obszarach i formach działalności wybranych muzeów.

Wyniki i wnioski: Badania pozwoliły stwierdzić, że wdrażanie w muzeach technologii cyfrowej jest procesem długotrwałym i dalekim od zakończenia, choćby z uwagi na pojawiające się ciągle nowe rozwiązania technologiczne. Polskie muzea obecnie nie wykorzystują wszystkich możliwości technologii cyfrowej, ale z uwagi na rosnące wymagania zwiedzających będą zapewne zmuszone do wdrożenia najnowocześniejszych rozwiązań.

Oryginalność/Wartość poznawcza: Artykuł prezentuje dziewięć obszarów działalności muzeów, w których można wykorzystać technologię cyfrową. Stanowi skrócone kompendium informacji z tej dziedziny wiedzy i praktyki, zilustrowane przykładami zastosowań poszczególnych technologii i narzędzi w dwóch muzeach poddanych analizie.
\end{abstract}

\section{Słowa kluczowe}

Aplikacje na urządzenia mobilne. Muzeum Historii Żydów Polskich POLIN. Muzeum Powstania Warszawskiego. Nowoczesna wystawa muzealna. Rzeczywistość rozszerzona. Serwisy społecznościowe. Sieci semantyczne. Technologia cyfrowa.

Otrzymany: 9 sierpnia 2016. Poprawiony: 14 stycznia 2017. Zaakceptowany: 24 stycznia 2017.

1 Artykuł powstał na podstawie pracy magisterskiej autorki, przygotowanej pod kierunkiem prof. Barbary Sosińskiej-Kalaty w Instytucie Informacji Naukowej i Studiów Bibliologicznych Uniwersytetu Warszawskiego (Zachara, 2016). 


\section{Wstęp}

Muzea w znanej nam formie liczą sobie niewiele ponad 200 lat, zaczęły bowiem powstawać masowo po Rewolucji Francuskiej, gdy zaistniała możliwość udostępnienia szerokiej publiczności skarbów sztuki i okazów przyrodniczych, zgromadzonych w prywatnych galeriach i gabinetach osobliwości. W ciągu tych dwóch stuleci muzea zmieniały się ewolucyjnie. Krzysztof J. Jakubowski (2010) wskazuje, że w procesie tym można wyróżnić trzy etapy: muzea platońskie - zamknięte, dostojne i poniekąd tajemnicze (np. Muzeum Książąt Czartoryskich, założone przez Izabelę Czartoryską w Puławach w 1801 r.), muzea sokratejskie - bardziej otwarte i do pewnego stopnia interaktywne (np. Muzeum Początków Państwa Polskiego, założone w 1956 r., które w 1983 r. uzyskało multimedialną wystawę stałą) oraz muzea, które z naszej perspektywy określamy jako nowoczesne (np. United States Holocaust Memorial Museum w Waszyngtonie, założone w 1993 r.). Zmiany te były wynikiem rozwijających się technologii, a także zmieniających się wymagań odbiorców. Najbardziej spektakularna zmiana, czyli powstanie muzeów nowoczesnych - tzw. trzeciej generacji, nastąpiła z chwilą upowszechnienia na przełomie XX i XXI wieku technologii cyfrowej. Coraz wyraźniej akcentowana funkcja edukacyjna i rozrywkowa placówek muzealnych stworzyła przestrzeń do zastosowania tej technologii w muzeach.

Celem artykułu jest zaprezentowanie, w jakim zakresie dwa znane polskie muzea: Muzeum Powstania Warszawskiego (dalej: MPW) i Muzeum Historii Żydów Polskich POLIN (dalej: Muzeum POLIN), wykorzystują w swej ofercie technologię cyfrową. Na podstawie analizy piśmiennictwa, w tym opracowania The 2010 Horizon Report: Museum Edition (Raport, 2010), na potrzeby analizy zagadnienia wyróżniono dziewięć obszarów stosowania technologii cyfrowej w muzeach:

(1) digitalizacja zasobów i udostępnianie ich w Internecie;

(2) nowoczesna wystawa muzealna;

(3) rozwiązania mobilne;

(4) serwisy społecznościowe;

(5) rzeczywistość rozszerzona;

(6) usługi wykorzystujące geolokalizację;

(7) sieci semantyczne;

(8) produkty cyfrowe;

(9) zarządzenie muzeum i udostępnianie jego usług online.

W kolejnych częściach artykułu przedstawiona jest charakterystyka każdego z poszczególnych obszarów, występujących w nich głównych pól i problemów aplikacyjnych oraz krótkie omówienie obecnego stanu zastosowania wymienionych technologii cyfrowych w omawianych polskich muzeach. Stan ten został przez autorkę ustalony na podstawie własnych analiz usług cyfrowych badanych muzeów i wystaw prezentowanych w ich siedzibach oraz wywiadów z pracownikami tych placówek, przeprowadzonych w ostatnim kwartale 2015 r. i w pierwszym półroczu 2016 r. Z uwagi na to, iż technologia cyfrowa bardzo szybko rozwija się, tuż przed publikacją dokonano w artykule uzupełnień, które obrazują dynamikę, z jaką muzea korzystają z możliwości tej technologii. 


\section{Digitalizacja zasobów i udostępnianie ich w Internecie}

\subsection{Digitalizacja obiektów muzealnych}

Podstawą wielu technik i usług cyfrowych (wirtualne muzea i wystawy tematyczne, aplikacje na smartfony, e-sklepy, spoty telewizyjne, multimedialne przewodniki, kopie zabytków wykonane w technologii 3D) jest digitalizacja obiektów muzealnych. Na proces ten składa się wiele elementów z różnych obszarów działania (Kłos i Nowacka, 2011). Z punktu widzenia wykorzystania nowoczesnych technologii cyfrowych najistotniejsze $w$ tym procesie są: wybór standardu digitalizacji i opisu zbiorów oraz metody archiwizacji cyfrowych odwzorowań zabytków. Kwestie te zostały szczegółowo omówione w pracy licencjackiej autorki (Zachara, 2014), przy znaczącym wykorzystaniu numeru 52 miesięcznika „Muzealnictwo”, traktującego o różnych aspektach digitalizacji, dostępnego w formie cyfrowej na stronie internetowej: http://muzealnictworocznik.com/index.php?p=1.

Istnieje wiele standardów odnoszących się do digitalizacji muzealiów oraz ich opisu. $\mathrm{Na}$ uwagę zasługują szczególnie te, które zostały wymienione w raporcie Narodowego Instytutu Muzealnictwa i Ochrony Zbiorów (NIMOZ), dotyczącym metadanych (Gaweł, 2012):

- Dublin Core Metadata Element Set (DC MES);

- Categories for Description of Works of Art (CDWA) - utworzony specjalnie na potrzeby muzeów;

- CDWA Lite - przy użyciu protokołu komunikacyjnego OAI-PMH pozwala na wymianę metadanych, zapisanych w różnych schematach;

- SPECTRUM - służący do dokumentacji i zarządzania kolekcjami muzealnymi, dostosowany do zgodności z Object ID (standardem stworzonym do rejestrowania i wykrywania obiektów przemieszczonych i skradzionych);

- Comité international pour la documentation Conceptual Reference Model (CIDOC CRM) - ontologia dziedzinowa, której podstawowym elementem jest trójelementowe wyrażenie o składni: „przedmiot - predykat - podmiot” (trójki takie mogą tworzyć długie łańcuchy logiczne, pozwalające na zbudowanie nigdy wcześniej nieistniejących powiązań) oraz

- Lightweight Information Describing Objects (LIDO) - schemat zaprojektowany do przekazywania informacji o muzealiach w ujednolicony sposób, tak, aby nadawały się do wyszukiwania i kwerend.

Bardzo istotnym aspektem digitalizacji są ograniczenia praw autorskich do digitalizowanych obiektów. Problem ten powraca w coraz nowszych odsłonach. Podobnie jak w odniesieniu do digitalizacji piśmiennictwa, również w odniesieniu do obiektów muzealnych, stale podnosi się kwestię sprzeczności interesów: prawo autorskie kontra prawo użytkowników do dostępu do informacji i wiedzy. Wyczerpującą wykładnię obecnego stanu prawnego w tym zakresie zawiera broszura wydana przez NIMOZ w 2014 r. (Kamińska, 2014).

Inny aspekt digitalizacji i udostępniania cyfrowych kopii obiektów muzealnych, a mianowicie bezpieczeństwo plików cyfrowych, porusza Luciana Duranti (2012). Zwraca ona uwagę na brak kontroli nad tym, kto i gdzie przechowuje pliki coraz częściej umieszczone obecnie w tzw. chmurze. Brak takiej kontroli rodzi pytania o zachowanie autentyczności powierzonych „chmurze” plików oraz o ich dostępność (niebezpieczeństwo wykasowania pewnych plików lub nieuprawnionego pobierania opłat za ich udostępnienie). 
The 2010 Horizon Report: Museum Edition (Raport, 2010) wskazuje, że digitalizacja zasobów muzealnych i odpowiednie ich skatalogowanie wymaga od muzeów znacznych nakładów środków finansowych, czasu i odpowiednio przygotowanych pracowników. Jest to jednak krok, którego nie można ominąć w pracy nowoczesnego muzeum, gdyż wszystkie lub prawie wszystkie omawiane dalej rozwiązania bazują na cyfrowej kopii zabytku. Nie wydaje się prawdopodobne, aby w dającej się przewidzieć przyszłości, zmalało znaczenie katalogowania zbiorów i ich digitalizacji. Wręcz przeciwnie - raport o muzeach, opracowany w 2015 r. i uzupełniony w 2016 r. wskazuje, że proces digitalizacji zabytków muzealnych wykazuje dużą dynamikę: trzykrotny wzrost w ciągu lat 2008-2012 (z ok. 280 tys. do ok. 837 tys. zdigitalizowanych muzealiów) (Raport, 2016).

Digitalizacja zasobów Muzeum Powstania Warszawskiego jest przeprowadzana własnymi siłami muzeum. Wykonuje się ją na bieżąco, w miarę napływu obiektów. Digitalizuje się obiekty muzealne, fotografie, negatywy, dokumenty. Wszystkie cyfrowe wizerunki muzealiów przechowywane są w bazie programu MUSNET. Na stronie internetowej wizerunki te pojawiały się w kilku miejscach: fotografie archiwalne - w Fototece, wybrane kopie zdjęć oraz obiektów muzealnych - w Wirtualnym Muzeum oraz na stronach Powstańcze biogra$m y$. W wyniku przebudowy portalu, obecnie (styczeń 2017 r.) dostępne są tylko fotografie archiwalne, zamieszczone w Fototece.

Muzeum POLIN w 2011 r. rozpoczęło realizację wieloletniego projektu digitalizacji zbiorów pod nazwą Centralna Baza Judaików. Projekt finansowany był ze środków Ministerstwa Kultury i Dziedzictwa Narodowego, w ramach programu Kultura+, którego operatorem jest Narodowy Instytut Audiowizualny. Muzeum POLIN digitalizowało przede wszystkim fotografie. Zdigitalizowane obiekty prezentowane są bezpłatnie w Internecie we wspomnianej już Centralnej Bazie Judaików. Do ich udostępniania używany jest program dMuseion. Celem Muzeum POLIN jest stworzenie cyfrowej bazy wszystkich judaików znajdujących się w Polsce. Judaika w formie cyfrowej można też oglądać na stronie internetowej Muzeum POLIN w formie wirtualnych wystaw oraz w elektronicznym katalogu zabytków (opis w dalszej części artykułu). Na szeroką skalę zostały one też wykorzystane przy konstruowaniu wystawy stałej, w urządzeniach z ekranami dotykowymi i w rzutnikach cyfrowych oraz do wykonania reprodukcji umieszczonych na wystawie.

\subsection{Serwisy/witryny internetowe}

Wykorzystywanie przez muzea serwisów i portali internetowych jest obecnie powszechne - według raportu „Muzea w Polsce”, wydanego w 2016 r., spośród 142 muzeów odpowiadających na pytanie ankietowe o prowadzenie strony internetowej, prawie 93\% placówek odpowiedziało pozytywnie (Raport, 2016). Serwisy te mają różny charakter i przeznaczenie, a ich jakość jest bardzo zróżnicowana. Stąd konieczność dokonywania ich oceny merytorycznej i formalnej. Wielu autorów tworzy własny zestaw kryteriów oceny stron internetowych. Np. Louis Rosenfeld i Peter Morville (2003) skupiają się na architekturze informacji, a Marcin Lehenstein-Werndl (2007) podkreśla ważność wygody użytkowania stron.

Serwis internetowy MPW do końca 2015 r. był bardzo rozbudowany. Było to wynikiem faktu, że składał się z trzech części projektowanych i wykonywanych przez niezależnych wykonawców. Zawierał on następujące elementy: główna witryna MPW - strona główna wraz 
z podstronami (http://www.1944.pl/), Wirtualne Muzeum (http://www.1944.pl/o_muzeum/ wirtualne_muzeum/) i Pierwsze dni (www.1944.wp.pl/pierwszedni/). Na początku 2016 r. Wirtualne Muzeum i Pierwsze dni zostały zamknięte w celu przeprowadzenia reorganizacji serwisu. Obecnie (styczeń 2017 r.) serwis wygląda zupełnie inaczej - pomiędzy sierpniem a październikiem 2016 r. uzyskał inną szatę graficzną, inny też jest sposób uporządkowania informacji w nim zawartych; Wirtualne Muzeum nie jest na razie dostępne. Serwis nadal jest przebudowywany, wiele jego dotychczasowych funkcji zostało zawieszonych lub usuniętych.

Z uwagi na bardzo szeroki zakres tematyczny zainteresowań Muzeum POLIN (historia, kultura, gospodarka, religia, prześladowanie i zagłada w czasie II wojny światowej), placówka zdecydowała się na prowadzenie kilku portali internetowych - głównego portalu muzealnego (www.polin.pl), portalu Polscy Sprawiedliwi - Przywracanie Pamięci - poświęconego czasom zagłady (http://www.sprawiedliwi.org.pl/pl/cms/strona-glowna/) oraz portalu Wirtualny Sztetl - poświęconego dziedzictwu żydowskiemu w różnych miejscowościach Polski (http://www.sztetl.org.pl/). Rozwijając serwis, w 2016 r. Muzeum POLIN uruchomiło kolejny portal - Żydowska Warszawa (http://warsze.polin.pl/pl/). Jest to multimedialny przewodnik po mieście, zawierający trzy zakładki, w których znajdują się treści skierowane do poszczególnych grup wiekowych.

Analizując strony internetowe obu muzeów stwierdzono, że:

- strony spełniają większość kryteriów podanych przez M. Lehensteina Werndla (2007) dla ergonomicznej i intuicyjnej strony internetowej;

- systemy organizacyjne serwisów obu muzeów są przede wszystkim chronologiczne, organizacja alfabetyczna pojawia się na kilku podstronach, zaś geograficzny system organizacyjny jest stosowany na portalu Wirtualny Sztetl, gdzie prezentowane są judaika w podziale na miejscowości oraz wskazane miejsca martyrologii Żydów w czasie II wojny światowej;

- w serwisach obu muzeów przeważają tekstowe systemy etykietowania, ikony pojawiają się wyjątkowo;

- obydwa muzea mają w swoich serwisach globalne systemy nawigacyjne - jest to menu umieszczone $u$ góry strony; lokalne systemy nawigacyjne umieszczono na wszystkich wymagających dodatkowego menu podstronach i są one bardzo dobrze zorganizowane oraz znajdują się w stałym miejscu; systemy pomocnicze nie wszędzie zostały zastosowane; nie stwierdzono natomiast nigdzie obecności indeksów ani przewodników po portalach;

- w serwisach obu muzeów zastosowano hierarchiczne struktury organizacyjne; w różnych miejscach serwisów zastosowano także struktury hipertekstowe;

- obydwa muzea stosują zarówno globalne jak i lokalne systemy wyszukiwania - globalna wyszukiwarka służy do wyszukiwania podstron serwisu zawierających żądaną frazę, natomiast wyszukiwarki lokalne przeszukują zasoby danej podstrony;

- autorstwo omawianych serwisów nie budzi wątpliwości - jest jednoznacznie określone przez wyraźną ikonę instytucji prowadzącej dany serwis; misja serwisu MPW nie jest zaprezentowana na stronie internetowej tej placówki; misja Muzeum POLIN jest zaprezentowana w sposób bardzo skrótowy; portal Polscy Sprawiedliwi - Przywracanie Pamięci oraz Wirtualny Sztetl zawierają podstrony zatytułowane „O projekcie”, ich zawartość można uznać za sprecyzowanie misji każdego z portali; portal Żydowska Warszawa nie posiada tekstu opisującego jego misję; 
- zakres tematyczny zamieszczanych treści jest bardzo spójny; w tym kontekście należy szczególnie podkreślić fakt, iż Muzeum POLIN prowadzi cztery serwisy internetowe z uwagi na bardzo szeroki zakres podejmowanych przez placówkę tematów;

- zakres chronologiczny zamieszczanych treści obejmuje dwa wymiary czasowe - jeden z nich to bieżąca działalność placówek muzealnych, a drugi - to interwał czasowy, do którego odnosi się działalność danego muzeum, oba muzea dobrze sobie radzą z oddzielaniem tych wymiarów, umieszczając informacje na odpowiednich podstronach;

- jakość informacji (aktualność, kompletność, użyteczność i wiarygodność) nie budzi wątpliwości i zastrzeżeń;

- wygląd opisywanych serwisów jest odpowiedni do zamieszczanych treści - portale odnoszące się do okresu II wojny światowej mają stonowaną kolorystykę i oszczędne środki wizualne, serwis Muzeum POLIN pełen jest kolorów odzwierciedlających kulturę żydowską, natomiast portal Wirtualny Sztetl ma kolorystykę i formę graficzną pośrednią w stosunku do opisanych powyżej. Ważne jest, że żaden z opisywanych serwisów i portali nie jest przeładowany efektami wizualnymi; grafika i multimedia stosowane są obficie, ale w sposób jak najbardziej współgrający z treścią serwisów;

- wszystkie omawiane serwisy są bezpłatne.

Należy podkreślić, że zawartość stron internetowych obu muzeów jest stale rozwijana. Wyrazem tego jest uruchomienie przez Muzeum POLIN serwisu Żydowska Warszawa oraz przebudowa serwisu Muzeum Powstania Warszawskiego podjęta w celu dostosowania jego wyglądu i funkcji do współczesnych standardów w tym zakresie.

\subsection{Archiwa tekstowe, dźwiękowe i obrazowe}

\subsubsection{Archiwum Historii Mówionej}

Jednym z działów fonoteki, szczególnie interesującym dla muzeów, jest archiwum historii mówionej. Historia mówiona (ang. oral history) to proces zapisu wypowiedzi uczestnika lub naocznego świadka wydarzeń. W zakres tego procesu wchodzi nie tylko nagrywanie wypowiedzi, ale również archiwizowanie nagrań i ich analiza merytoryczna. Zdaniem Izabeli Skórzyńskiej (2014) historia mówiona w znaczący sposób wzbogaca ekspozycje muzealne, dając możliwość doświadczenia głosu i widoku świadków przeszłości.

Analizowanie wypowiedzi z zakresu oral history odbywa się na płaszczyźnie historycznej i socjologicznej. Tradycyjna historiografia jest nieufna wobec tego źródła, gdyż jest ono subiektywne i naznaczone emocjami. Odpowiedzią na te zastrzeżenia może być opracowanie odpowiedniej metodologii krytyki tego rodzaju źródeł. Historia mówiona jest wykorzystywana do działalności dokumentacyjnej, wystawienniczej i edukacyjnej.

Archiwum Historii Mówionej w Muzeum Powstania Warszawskiego (http://www.1944. pl/historia/archiwum_historii_mowionej/) działa od października 2004 r. Jego zadaniem jest zebranie relacji żyjących uczestników Powstania Warszawskiego - żołnierzy AK. Wszystkie świadectwa zebrane są w formie elektronicznej i udostępniane na internetowej stronie muzeum. Fragmenty relacji zamieszczane są również na kanale YouTube. W listopadzie 2015 r. zebranych było 4000 nagrań (około 8000 godzin). MPW dąży do umieszczenia wszystkich zasobów tego archiwum w Internecie, co pozwoli na korzystanie z nich w dowolnym momencie, dogodnym dla użytkownika. W styczniu 2017 r. na nowej stronie 
internetowej muzeum dostępnych jest 3276 wywiadów z powstańcami, zamieszczono je w formie tekstowej, nie jest dostępna możliwość odsłuchania wywiadu. Oczywiście archiwum to jest dostępne również w siedzibie muzeum. Na bazie zebranych nagrań przygotowano i wydano dwie płyty DVD: Kanały i Poza walka. Życie codzienne w Powstaniu Warszawskim. Przygotowano też publikację książkową Powstanie w Ich Pamięci.

Muzeum POLIN zrealizowało Archiwum Historii Mówionej we współpracy z Narodowym Instytutem Audiowizualnym (NInA). Archiwum to liczy ponad 200 wywiadów. Po zakończeniu opracowywania całość będzie dostępna w siedzibie NInA (jako właściciela projektu) oraz w Centrum Informacyjnym Muzeum POLIN. Na stronie internetowej NInA będą dostępne krótkie (kilkuminutowe) miniwywiady, mające na celu zachęcenie do zapoznania się z całością nagrań (w styczniu 2017 r. nagrania te jeszcze nie były dostępne). Muzeum POLIN nie planuje umieszczenia tego archiwum na swojej stronie internetowej, wychodząc z założenia, że najważniejsze jest to, aby osoba zainteresowana przyszła do muzeum, a nie to, aby jej ciekawość została zaspokojona całkowicie przez stronę internetową. Na podstawie nagrań zgromadzonych w Archiwum Historii Mówionej opracowywane są liczne materiały edukacyjne Muzeum POLIN. Osobne archiwum historii mówionej znajduje się na portalu Polscy Sprawiedliwi - Przywracanie Pamięci. Nosi tam ono nazwę audioteki (http://www.sprawiedliwi.org.pl/pl/cms/audioteka/).

\subsubsection{Fototeka}

MPW gromadzi zarówno fotografie archiwalne - dokumentujące Powstanie Warszawskie, jak i fotografie dokumentujące własną działalność. Zdjęcia z obu tych kategorii były dostępne na stronie internetowej muzeum w zakładce Galerie. Zdjęcia współczesne zamieszczono w podkategorii Galerie Zdjęć (http://www.1944.pl/galerie/galerie_zdjec/), a archiwalne w Fototece (http://www.1944.pl/galerie/fototeka/). W wyniku zmian wprowadzonych w serwisie, obecnie (styczeń 2017 r.) dostępna jest tylko Fototeka.

Digitalizacja fotografii z okresu Powstania (zarówno pozytywów jak i negatywów) jest przeprowadzana własnymi siłami muzeum, konsekwentnie od początku jego istnienia, na bieżąco w trakcie gromadzenia kolekcji. Wszystkie fotografie wprowadzone do inwentarzy mają swoje postacie cyfrowe według obowiązujących standardów digitalizacyjnych. W zakładce Fototeka (http://www.1944.pl/fototeka/) znajduje się obecnie (styczeń 2017 r.) ok. 8000 fotografii. Stanowi to około $25 \%$ zdigitalizowanego zasobu. Relatywnie niewielki procent udostępnionych fotografii jest spowodowany tym, że na stronie internetowej zamieszczone są tylko te zdjęcia, do których muzeum pozyskało licencję praw autorskich. Fotografie podzielone są na kategorie ułatwiające wyszukiwanie. Zdjęcia można oglądać pojedynczo, wraz z ich opisem. W poprzedniej wersji serwisu możliwe było też uruchomienie pokazu slajdów - wyświetlały się wtedy kolejno zdjęcia z wybranej kategorii.

Archiwum fotograficzne Muzeum POLIN zostało pomyślane jako zbiór rozproszony $\mathrm{z}$ uwagi na to, że muzeum prowadzi kilka portali o różnym profilu, na każdym z nich zamieszczane są fotografie odpowiadające profilowi danego portalu. Wszystkie fotografie zgromadzone są w jednej bazie na serwerach muzeum i stamtąd są dystrybuowane do poszczególnych portali, w zależności od potrzeb. 


\subsection{Udostępnianie e-kopii obiektów muzealnych $w$ Internecie}

Prezentowanie zbiorów muzealnych w sieci WWW jest naturalną kontynuacją tradycji publikowania katalogów zbiorów muzealnych. Z natury rzeczy katalogi te nie stanowiły konkurencji dla osobistego obcowania ze zbiorami muzealnymi. Istnieje kilka sposobów prezentowania zabytków w Internecie.

\subsection{1. e-Kopia zabytku muzealnego}

Najprostszym sposobem przedstawienia zabytków muzealnych jest zamieszczenie fotografii lub skanu pojedynczego obiektu, uzupełnionego odpowiednim opisem. Czasami takie odwzorowania łączy się tematycznie w galerie. Nie jest to jednak katalog zabytków, gdyż nie posiada odpowiedniej formy prezentacji zbiorów oraz wymaganych w katalogu elementów opisu. Wiele muzeów korzysta z tego rozwiązania w sytuacji, gdy nie dysponuje elektronicznym katalogiem zbiorów lub wtedy, gdy chce przyciągnąć uwagę internautów szczególnie wartościowymi obiektami.

Oba muzea, w których prowadzono badania nie prezentują zabytków w formie oderwanej od kontekstu danych przedmiotów, co należy zaliczyć do zalet ekspozycji.

\subsection{2. e-Katalog zabytków}

Elektroniczny katalog zabytków umieszczony na stronie internetowej placówki muzealnej pełni rolę informacyjną i jest zachętą do odwiedzenia muzeum. Nie stanowi konkurencji dla obiektów umieszczonych w muzeum, ale przyczynia się do ożywienia pracy naukowej, umożliwiając wymianę informacji o zabytkach pomiędzy zainteresowanymi placówkami specjalizującymi się w różnych dziedzinach i mieszczącymi się w dowolnym miejscu na świecie. Przewaga katalogu elektronicznego nad tradycyjnym polega na łatwości jego aktualizacji oraz większych możliwościach wyszukiwawczych, które oferuje dzięki zastosowaniu różnorodnych filtrów i faset. Katalog taki umożliwia prezentację całości kolekcji, na co w rzeczywistości nie może sobie pozwolić żadne, nawet największe i najbogatsze muzeum.

W 2014 r. tylko 18 polskich muzeów udostępniało swoje zbiory w formie katalogu internetowego (Żywek, 2015). Powodów takiego stanu rzeczy upatrywało się w następujących trudnościach: obawa przed kradzieżą wizerunków zabytków, trudności natury technicznej (opóźnienia w procesie digitalizacji, brak pracowników wprowadzających na bieżąco metadane zdigitalizowanych obiektów, dobór odpowiedniego oprogramowania), obowiązujące prawo autorskie, problemy z opracowaniem zbiorów (nieukończenie opracowania kolekcji muzealnej, niepewność co do prawidłowości opracowania), problemy z opracowaniem odpowiednich słowników opisujących zabytki w sposób jak najbardziej jednolity, brak tłumaczenia już istniejących słowników/tezaurusów na inne języki, opory dyrekcji i pracowników przed udostępnieniem katalogu w Internecie (obawa, że nikt nie będzie przychodził do muzeum oraz strach, że muzealia zostaną skradzione, skoro powszechnie będzie wiadome, gdzie się znajdują).

Obecnie, według NIMOZ, już 41 placówek muzealnych promuje swoje zasoby w formie katalogu internetowego (stan na grudzień 2016 r.) (zob. Internetowe katalogi zbiorów polskich muzeów i instytucji naukowych, http://digitalizacja.nimoz.pl/baza-wiedzy/katalogi-zbiorow). Zmiana ta jest związana z coraz powszechniejszą wśród muzealników 
znajomością Internetu. Niebagatelną rolę w tym procesie odgrywa też konieczność dostosowania oferty muzealnej do nowej generacji użytkowników, przyzwyczajonych do wyszukiwania informacji online.

MPW nie prezentuje w Internecie katalogu swoich zabytków.

Muzeum POLIN jest jednym z ciągle jeszcze nielicznych muzeów, które udostępniają zgromadzone zabytki w formie katalogu internetowego. Nosi on nazwę Centralna Baza Judaików. Prace nad nim rozpoczęto w 2011 r. Są w nim zgromadzone muzealia z własnych zbiorów Muzeum POLIN oraz depozyty Żydowskiego Instytutu Historycznego. Docelowo baza ta ma obejmować wszystkie pamiątki kultury i dziedzictwa żydowskiego, zgromadzone w polskich instytucjach kultury. Do programu włączyły się kolejne instytucje, posiadające w swych zasobach różne judaica. Obecnie (styczeń 2017 r.) w bazie prezentowanych jest ponad 5200 judaików. Katalog znajduje się pod adresem http://judaika.polin.pl/dmuseion/. Skatalogowane obiekty pogrupowano według dwóch różnych kryteriów - pierwsze z nich to podział rzeczowy (dzieła sztuki, pamiątki historyczne, synagogalia), a drugie - przynależność do placówki kultury. Zamieszczona na stronie katalogu wyszukiwarka pozwala na wybieranie obiektów według szesnastu kryteriów. Wyszukiwarka pozwala na skonstruowanie rozbudowanego zapytania (wraz z powtórzeniami kryterium), którego poszczególne elementy łączy się za pomocą operatorów Boole’a. Wynik wyszukiwania podawany jest w postaci listy miniatur ze skróconym opisem, wyświetlana jest też liczba znalezionych obiektów, spełniających podane kryteria. Istnieje możliwość wydrukowania karty katalogowej wraz ze zdjęciem, zapisania na dysku, udostępnienia w portalach społecznościowych oraz dodania do schowka.

\subsubsection{Wirtualna wystawa}

Wirtualna wystawa jest podobna do przedstawionego wyżej elektronicznego katalogu zabytków. W odróżnieniu od niego wybrane, zdigitalizowane zabytki łączy się w kolekcje, czyli wystawy (nazywane też galeriami), a całość opatruje się odpowiednim komentarzem ogólnym. Atrakcją wystaw wirtualnych są zabytki skanowane w technologii 3D, która umożliwia oglądanie obiektu ze wszystkich stron. Warto też podkreślić możliwość wielokrotnego powiększenia na ekranie całego zabytku lub jego fragmentu. Funkcja ta jest szczególnie ceniona przez naukowców, hobbystów oraz osoby słabo widzące.

Za wirtualną wystawę MPW można uznać dawną podstronę Ekspozycja (http://www.1944. pl/o_muzeum/ekspozycja/), która przybliżała użytkownikowi Internetu zasoby muzeum. Jej centrum zajmowała interaktywna mapa pozwalająca na „przemieszczanie się” po kondygnacjach i sektorach muzeum. W każdym z nich można było oglądać umieszczoną nad mapą galerię zdjęć prezentujących dany fragment ekspozycji i przeczytać dokładniejszy jej opis. Każde zdjęcie było podpisane. Na wybranym przez użytkownika poziomie budynku muzealnego w miejsce mapy ogólnej ukazywała się interaktywna mapa tego poziomu, pozwalająca z kolei na wybranie opisu wskazanego tematu ekspozycji (a czasem pojedynczego eksponatu). Nawigacja była intuicyjna. Menu, zarówno boczne (rozwijalne) jak centralne na interaktywnej mapie (mapach) pozwalało elastycznie przeglądać interesujące użytkownika części ekspozycji lub oglądać je sekwencyjnie. W funkcjonującym obecnie serwisie podstrona ta nie jest dostępna.

Muzeum POLIN przygotowało kilka wirtualnych wystaw: Dom pod zwariowana gwiaz$d q$ - o Żydach ukrywanych w czasie okupacji w warszawskim ZOO, Kochanej Mamósi 
na pamiatke (oryginalny zapis) - o dzieciach ocalonych z Zagłady, Dobry adres - historie ukrywania Żydów w okupowanej Warszawie, Polscy artyści z pomoca Żydom, Żegota oraz Jak zrobić muzeum, Biografie rzeczy, 1000 lat historii Żydów polskich i Odzyskać opowieść. Sposób nawigacji po wystawach jest intuicyjny, niektóre z nich oparte są na jednakowym schemacie nawigacyjnym. Wystawy wirtualne są dostępne kolejno lub równolegle w serwisie głównym Muzeum POLIN oraz na portalu Polscy Sprawiedliwi - Przywracanie Pamięci (http://www.sprawiedliwi.org.pl/pl/cms/wystawy/), ponadto udostępniane są na platformie Google Cultural Institute, co znacząco zwiększa ich oglądalność.

\subsubsection{Wirtualne muzeum}

W definiowaniu tego sposobu prezentacji zabytków występują znaczne rozbieżności. Niektórzy mianem wirtualnego muzeum określają dowolny zbiór plików powstały podczas digitalizacji zabytków. Inni precyzują, że wirtualne muzeum to bardziej skomplikowana aplikacja, odtwarzająca nie tylko wygląd zabytków, ale również sal muzealnych, w których się one znajdują (z zastosowaniem grafiki 3D lub technologii panoram sferycznych). Często do prezentowanych zdjęć dołącza się tekst, muzykę czy komentarz słowny. Istnieje też możliwość uczestniczenia w dyskusjach w wirtualnym muzeum, toczonych na forum lub na czacie (Stefanik \& Kamel, 2013).

Wirtualne muzea są skierowane do wszystkich, mają zachęcić do odwiedzenia placówki. Tym, którzy z różnych powodów nie mogą przybyć do muzeum (choroba, znaczna odległość itp.) dają możliwość obcowania z zabytkami w postaci galerii zdjęć o bardzo wysokiej rozdzielczości (Barycki, 2014; Pawłowska \& Matoga, 2014). Z uwagi na coraz większy odsetek osób starszych i niepełnosprawnych ideę wirtualnych muzeów popularyzuje się wśród tych grup społecznych.

Do końca 2015 r. MPW posiadało portal Wirtualne Muzeum (www.1944.pl/o_muzeum/ wirtualne_muzeum/), będący niezależną częścią serwisu internetowego muzeum. Uruchomiono go oficjalnie 22 kwietnia 2008 r., choć jego pierwsza, niepełna odsłona miała miejsce 1 sierpnia 2006 r. Projekt oparto na technologii flash i obrazu 3D, uzupełniając go dźwiękiem i pokazem wideo, co zapewniało wysoki poziom interakcji. W grudniu 2008 r. strona uzyskała nagrodę WebstarFestival w kategorii Kultura - wtedy był to jedyny w polskim Internecie konkurs na najlepsze strony WWW. Wirtualna wycieczka odbywała się poprzez wybranie na interaktywnym planie muzeum poziomu, który chce się zwiedzać, a następnie oglądanie prezentowanych na ekranie treści i odsłuchiwanie nagranego komentarza. Wirtualne Muzeum posiadało podstronę Mur Pamięci (www.1944.wp.pl/index2.php?\#0), powiązaną z bazą danych. Zamieszczona tu wyszukiwarka pozwalała na odnalezienie na Murze Pamięci nazwiska szukanej osoby. W wyniku wyszukiwania podawany był numer kolumny, rzędu i pozycji nazwiska w polu Muru. Po kliknięciu na te dane, zdjęcie Muru ustawiało się w takiej pozycji, aby było widoczne wyszukane nazwisko.

Jak wspomniano wcześniej, Wirtualne Muzeum zostało zamknięte na początku 2016 r. w celu reorganizacji i pełnej integracji z głównym serwisem internetowym MPW. Jak dotychczas (styczeń 2017 r.) portal nie został ponownie uruchomiony.

Muzeum POLIN oferuje użytkownikom swojej strony internetowej wirtualny spacer po wystawie stałej, oparty na technologii Street View. Spacer uruchomiono w październiku 2014 r., Muzeum POLIN było pierwszym polskim muzeum korzystającym z tej możliwości. Spacer jest dostępny w zakładce Wystawy/Wystawa stała/Wirtualny spacer po wystawie 
(http://www.polin.pl/pl/aktualnosci/2016/02/15/udaj-sie-w-wirtualny-spacer-po-wystawie-stalej). Poruszanie się po wirtualnym muzeum nie jest intuicyjne - dostępne są strzałki w kolistym białym polu, białe strzałki na środku dolnej części widoku sali muzealnej oraz jasne pole w kształcie prostokąta lub elipsy, pojawiające się po najechaniu myszką na obszar prezentacji. Użytkownik nie jest w żaden sposób poinformowany, z której możliwości należy skorzystać i czym się one różnią pomiędzy sobą.

\section{Nowoczesna wystawa muzealna}

Drugi obszar zastosowań nowoczesnej technologii cyfrowej w muzealnictwie stanowią ekspozycje tworzone w salach muzeów. Na nowoczesną wystawę muzealną składa się wiele czynników: interaktywność, zastosowanie urządzeń multimedialnych (w tym możliwość sterowania nimi za pomocą gestu), modele i kopie zabytków wykonane w technologii 3D oraz odpowiednio zaprogramowane audioprzewodniki.

\subsection{Wystawa interaktywna}

Wystawa interaktywna to taki rodzaj wystawy muzealnej, która daje zwiedzającemu możliwość uczestnictwa w zjawiskach, które może on sam wywołać za pomocą różnych działań podczas zwiedzania. Często też ma możliwość doświadczania eksponatu nie tylko wzrokiem, ale również innymi zmysłami: dotykiem, słuchem, węchem, czasem nawet smakiem. Jednym z elementów interaktywności (zwłaszcza w muzeach historycznych) jest to, że wystawa nie narzuca jednej obowiązującej interpretacji przedstawianego zjawiska, ale pokazując je z możliwie wielu perspektyw, pozostawia ocenę widzowi (Stefanik \& Kamel, 2013).

\subsection{Kioski multimedialne}

Kioski multimedialne to urządzenia interaktywne. Mają one zazwyczaj ekran dotykowy, głośniki, a czasem słuchawki i klawiaturę. Na ekranie wyświetlają się zaprogramowane treści. W muzeach kioski takie wykorzystuje się w różnorodny sposób. Są stanowiska pozwalające na odsłuchanie przygotowanych plików dźwiękowych; są takie, które pozwalają na obejrzenie wybranych eksponatów w dużym powiększeniu, uzupełniając obraz informacją tekstową i hologramem.

\subsection{Projektory/rzutniki multimedialne}

Projektor/rzutnik jest to urządzenie optyczne, wyświetlające obraz na ekranie, na podstawie otrzymanego sygnału elektronicznego. Sygnał ten może pochodzić z komputera stacjonarnego lub przenośnego, magnetowidu, kamery, odtwarzacza DVD lub tunera satelitarnego.

\subsection{Sterowanie gestami}

Sterowanie gestami to taki rodzaj interakcji człowieka z urządzeniem, który opiera się na odczytywaniu przez maszynę naturalnych ruchów ludzkiego ciała i odpowiedniej reakcji 
na ten ruch. Obecnie na rynku dostępne są urządzenia sterowane naturalnymi ruchami palców (dotknięcie, przesunięcie, rozciągnięcie, zwężenie). W The 2010 Horizon Report: Museum Edition przedstawiono wykorzystywanie urządzeń, które za pomocą kamer i sensorów odbierają ruch naszych ciał.

\subsection{Modele i kopie zabytków drukowane w technologii 3D}

Wykonanie trójwymiarowego modelu (kopii) zabytku wymaga bardzo dokładnego zeskanowania obiektu oryginalnego. Skanowanie wykonuje się za pomocą lasera, uzyskując tzw. chmurę punktów, którą następnie modeluje się komputerowo, tworząc odwzorowanie zabytku oparte na siatce wielokątów. Tak opracowany model można wydrukować na nowoczesnej drukarce 3D, która za pomocą dysz wypuszcza w odpowiednich porcjach zastygającą stopniowo masę plastyczną. Zaletą tej techniki jest możliwość wykonania nieograniczonej liczby kopii raz zeskanowanego zabytku. Kopie te mogą być wykonane w różnej skali i służyć jako pamiątki z muzeum lub jako pomoce dla osób niewidomych.

\subsection{Audioprzewodniki i przewodniki multimedialne}

Początki audioprzewodników i przewodników multimedialnych w muzeach sięgają lat 50. XX wieku. Obecnie urządzenia te znajdują się w bardzo wielu muzeach, oferując komentarz do zwiedzania w wielu językach. Można też pobrać taki przewodnik (przeważnie w postaci pliku MP3) na swoje urządzenie mobilne.

Część muzeów oferuje zwiedzającym audioprzewodniki spersonalizowane. Funkcja ta polega na uprzednim (jeszcze przed udostępnieniem urządzenia osobom zwiedzającym) zaprogramowaniu określonej ścieżki zwiedzania ekspozycji - np. dla dorosłych, dla dzieci, dla rodzin z małymi dziećmi, dla naukowców. Użytkownik zgłaszając się po audioprzewodnik określa, jaka ścieżka zwiedzania go interesuje.

Technologie lokalizacyjne (transmisja radiowa, podczerwień) pozwalają też na adaptację treści odtwarzanych przez audioprzewodnik - odpowiednio zaprogramowane urządzenie dostosowuje odtwarzany komentarz do miejsca, w którym znajduje się użytkownik (istnieje możliwość wygenerowania różnych komunikatów w zależności od tego, czy zwiedzający był już w danym pomieszczeniu czy jeszcze nie), naprowadza go też na właściwą drogę zwiedzania, jeśli pomylił pomieszczenia (Marzec \& Krynicki, 2015).

Audioprzewodnik może być zintegrowany z innymi multimediami: ekranami dotykowymi, kioskami multimedialnymi, ekranem kinowym, na którym wyświetla się film.

\subsection{Wykorzystanie narzędzi nowoczesnych wystaw w Muzeum Powstania Warszawskiego i Muzeum POLIN}

W MPW zbudowano wystawę, wykorzystując najnowsze rzutniki, monitory i kioski multimedialne, dostępne w 2004 r. Zamontowano kilkaset takich urządzeń, starannie rozplanowując ich rozmieszczenie i rolę, którą mają pełnić. Najwięcej jest monitorów, na których odtwarzane są filmy i relacje świadków. Zastosowano też wiele rzutników. $\mathrm{Na}$ monitorach i ekranach dotykowych prezentowana jest różnorodna zawartość. Interaktywność wystawy realizuje się przez umieszczenie ekranów dotykowych z bogatą 
zawartością, przez możliwość dotykania niektórych eksponatów czy drukowania ulotek na prawdziwej maszynie drukarskiej. Nie stwierdzono wykorzystania modeli wydrukowanych na drukarkach 3D. Na wystawie skorzystano z możliwości kodowania dodatkowych informacji za pomocą kodów QR. Kody umieszczono przy eksponatach, którym towarzyszy płynący z głośników komentarz słowny. Odczyt kodu urządzeniem mobilnym powoduje wyświetlenie na ekranie tego urządzenia komentarza w polskim języku migowym. Stosowane w muzeum audioprzewodniki są to urządzenia odtwarzające nagranie z karty pamięci (informacje nagrano w 26 językach), nie posiadają funkcji lokalizacji przestrzennej.

Muzeum POLIN korzysta na wystawie stałej z bardzo wielu ekranów dotykowych, rzutników, monitorów i komputerów. Urządzeń tych jest kilkaset, prezentowana jest w nich różnorodna zawartość. Interaktywność wystawy stałej realizuje się przez umieszczenie bardzo wielu ekranów dotykowych z bogatą zawartością. Każdy ze zwiedzających, zainteresowany innymi szczegółami przekazu, może na każdym z ekranów wybrać ważne dla niego „porcje” informacji (bo nie sposób zapoznać się ze wszystkimi). Wystawa stała Muzeum POLIN została zakupiona jako projekt autorski, pracownicy muzeum nie są w stanie udzielić odpowiedzi na pytanie, czy przy tworzeniu makiet do wystawy korzystano z technologii druku 3D. Muzeum wykorzystuje tradycyjne audioprzewodniki. Urządzenia te nie posiadają najnowszych funkcji lokalizowania użytkownika w przestrzeni budynku. Treść odtwarzanych informacji nie jest spersonalizowana, ale dostępna jest w kilkunastu językach. Dostępne są też audioprzewodniki dla osób z dysfunkcjami słuchu - wyposażono je w ekran, na którym widoczny jest tłumacz polskiego języka migowego. Dla osób niewidomych i słabowidzących przygotowano audioprzewodnik ze 150-minutową audiodeskrypcją oraz zestaw tyflografik przedstawiających wybrane elementy wystawy stałej. Również z myślą o niewidomych przygotowano audiodeskrypcję spaceru pt. „Odkryj muzeum" (plik dźwiękowy można pobrać ze strony internetowej).

\section{Rozwiązania mobilne}

Autorzy The 2010 Horizon Report: Museum Edition zauważają, że urządzenia mobilne zatarły granicę pomiędzy siecią telefoniczną a Internetem. Spowodowało to uniezależnienie tych urządzeń (i ich użytkowników) od sieci elektrycznej. Muzea mogą wykorzystać urządzenia mobilne do integrowania treści znajdujących się w murach muzeów i poza nimi, a także do wspomagania edukacji i interpretacji przedstawianych treści oraz do umieszczania informacji w bardzo szerokim kontekście. Do wykorzystania na urządzeniach mobilnych można przygotować aplikacje lub strony internetowe.

\subsection{Aplikacje na urządzenia przenośne (smartfony, tablety)}

Aplikacje na urządzenia przenośne są to pliki cyfrowe zawierające różnorodne treści, przeznaczone do użytkowania na nowoczesnych urządzeniach elektronicznych - zwłaszcza smartfonach i tabletach. Wykorzystują one obraz, dźwięk, animację, rozszerzoną rzeczywistość oraz geolokalizację (GIS: Geographic Information System), łącząc je w tematyczną całość. W Polsce prekursorką aplikacji muzealnych była Zuzanna Stańska, zwyciężczyni 
międzynarodowego konkursu Young Creative Enterpreneur dla młodych kreatywnych przedsiębiorców w 2014 r. (Britisch Council, 2014).

Polscy muzealnicy coraz bardziej doceniają wartość takich rozwiązań. Według badań ankietowych z 2014 r., spośród 140 muzeów, które udzieliły odpowiedzi na pytanie o stosowanie aplikacji mobilnych, 17 placówek zadeklarowało, że ma je w swojej ofercie - naliczono łącznie 29 aplikacji, czyli średnio po dwie w każdym muzeum, które wdrożyło te rozwiązania (Raport, 2016).

MPW przygotowało kilka aplikacji mobilnych. Warszawa'44. Śladami Powstania Warszawskiego - zrealizowana w 2011 r., zawiera informacje o 73 miejscach, związanych z Powstaniem Warszawskim. W konstrukcji aplikacji wykorzystano rzeczywistość rozszerzoną (współpraca odbiornika GPS, kamery i kompasu wbudowanych w urządzenie mobilne, z bazą obiektów dotyczących Powstania i informacji o nich); Miejsca Pamięci - Warszawa'44 - stanowi nowszą wersję powyższej aplikacji; Pamięć miasta - została przygotowana w 2014 r., zawiera opisy i zdjęcia miejsc upamiętniających walkę powstańczą (wszystkie te obiekty zostały umieszczone na wirtualnej mapie); Archimapa - multimedialny dwujęzyczny przewodnik po architekturze Warszawy, wyprodukowany w 2015 r., przedstawia siedem zagadnień związanych z architekturą stolicy w XX wieku. Wszystkie aplikacje są dostępne w sklepach internetowych dystrybuujących aplikacje mobilne, są bezpłatne.

Muzeum POLIN udostępniło w 2012 r., jako pierwsze muzeum w Polsce, aplikację na smartfony My Warsaw - Warszawa jest moja; przedstawia ona Warszawę z czasów Janusza Korczaka. Obecnie muzeum pracuje nad nową wersją tej aplikacji. W 2014 r. z okazji 71 rocznicy powstania w getcie warszawskim udostępniono aplikację Żonkile. Została ona pomyślana w ten sposób, że uczestnicy akcji wykonywali zdjęcie żonkila, a następnie za pomocą udostępnionej aplikacji zamieszczali je na Facebooku. Nadsyłane zdjęcia układały się na mapie Warszawy w obrys historycznych granic getta. Inną aplikacją oferowaną przez Muzeum POLIN jest PointFinder. Pojawiła się ona pod koniec 2015 r. Zawiera interaktywny plan muzeum, najciekawsze obiekty wystawy stałej, opis wszystkich galerii oraz informacje o bieżących wydarzeniach w muzeum.

\subsection{Strony internetowe na urzadzenia mobilne}

Istnieją dwa rodzaje stron internetowych przeznaczonych na urządzenia mobilne: strony mobilne oraz strony responsywne. Oba rodzaje szczegółowo opisuje Krzysztof Kozieł (2013) na blogu Enzo. Strony mobilne to specjalne wersje stron internetowych, dostosowane do wymogów urządzeń mobilnych. Od stron przeznaczonych na urządzenia stacjonarne różnią się grafiką, nawigacją, treścią oraz domeną. Strony responsywne to takie strony, których zawartość płynnie dostosowuje się do rozdzielczości ekranu. Zmiany te mogą dotyczyć wyglądu, ale też nawigacji i zawartości strony. Adres URL takiej strony jest niezmienny.

MPW przygotowało responsywną stronę internetową na urządzenia mobilne - www. warsawrising.eu. Stanowi ona interaktywne uzupełnienie wystawy „Powstanie Warszawskie 1944", prezentowanej w okresie od 29 lipca do 26 października 2014 r. w Centrum Dokumentacyjnym „Topografia Terroru” w Berlinie. Strona otrzymała wiele nagród i wyróżnień, m.in.: I nagrodę na międzynarodowym konkursie Webby Awards 2015 na najlepszą stronę internetową na świecie w kategorii „Instytucja kultury”. Otrzymała także tytuł strony miesiąca od prestiżowego portalu AWWWARDS, nagradzającego najlepsze 
projekty internetowe na świecie, i nagrodę Mobile Trends w kategorii „Firma z najlepszą stroną mobilną" (wp.pl, 2015).

Muzeum POLIN przygotowało mobilną wersję portalu Wirtualny Sztetl (http://www. sztetl.org.pl/m/).

\section{Serwisy społecznościowe}

Serwisy i portale społecznościowe są darmowymi kanałami komunikacji elektronicznej, które funkcjonują w oparciu o swobodnie organizującą się społeczność. Oferują bardzo łatwe komunikowanie różnych treści: tekstów, obrazów, dźwięków. Tworzą one tzw. media społecznościowe (ang. social media), umożliwiające tworzenie i wymianę treści wygenerowanych przez użytkowników. Oprócz typowych mediów społecznościowych istnieje też kanał YouTube (do prezentowania filmów), wpisujący się w nurt darmowych zasobów użytkowników.

W The 2010 Horizon Report: Museum Edition zwrócono uwagę na fakt, że media społecznościowe dają możliwość dotarcia do nowych odbiorców i tworzenia społeczności wokół zbiorów muzealnych. Umożliwiają też merytoryczną dyskusję na temat prezentowanych treści i ułatwiają uczenie się. W raporcie podkreślono też wartość „zbiorowej inteligencji”, czyli zdolności grupy osób do podnoszenia poziomu wiedzy poprzez współpracę; daje to szansę na ujawnienie wiedzy, która była ukryta - jako przykład podano zamieszczenie w serwisie społecznościowym kolekcji zdjęć, które były nierozpoznane przez muzealników, a które udało się zidentyfikować dzięki wiedzy jednego z internautów.

Coraz więcej polskich muzeów dostrzega korzyści płynące z obecności placówki w mediach społecznościowych. Badanie statystyczne dotyczące tego zagadnienia, przeprowadzone w 2014 r. pokazało, że ponad 80\% muzeów, które odpowiedziały na to pytanie ankietowe, jest obecnych w mediach społecznościowych (Raport, 2016).

Obydwa muzea poddane analizie chętnie korzystają z mediów społecznościowych.

MPW posiada profil na Facebooku. Pierwszy wpis pochodzi z 6 grudnia 2009 r. Według stanu na dzień 20 lutego 2016 r. wskaźnik polubień wynosił 212 687. Rok później zarejestrowano 229511 polubień (stan na 18 stycznia 2017 r.). W 2016 r. przejściowo profil był dostępny wyłącznie dla osób zalogowanych, czyli posiadających własne konta na Facebooku. Praktyka ta dotyczyła bardzo wielu kont na tym portalu. Obecnie (styczeń 2017 r.) profil jest dostępny bez konieczności logowania.

Muzeum POLIN gromadzi wokół siebie fanów i sympatyków na kilku portalach społecznościowych - Facebooku, Twitterze i Instagramie, wykorzystując te media do kontaktów z różnymi grupami odbiorców. Kanał YouTube wykorzystywany jest do zamieszczania krótkich filmów przedstawiających działania muzeum oraz relacji z wydarzeń kulturalnych w tej placówce. Profil na Facebooku, podobnie jak profil MPW, przez pewien czas w 2016 r. był dostępny wyłącznie po zalogowaniu, obecnie to obostrzenie zostało usunięte. Liczba polubień profilu muzeum na koniec 2015 r. wynosiła na Facebooku 38 675, natomiast na Twitterze odnotowano 2012 obserwujących, a na Instagramie - 4040. Obecnie (styczeń 2017) dane te przedstawiają się następująco: Facebook - 50804 polubień i 48938 obserwujących, Twitter - 3130 obserwujących, Instagram - aż 10.3 tys. obserwujących.

Muzeum jest także obecne w Instytucie Kultury Google, prezentuje tam opisany wyżej wirtualny spacer po wystawie stałej oraz wystawy czasowe. Ponadto muzeum prowadziło 
projekt crowdsourcingowy HistoriePolin.pl, zbierający świadectwa spotkań z kulturą żydowską. Trzeci etap tego projektu zakończył się 15 grudnia 2015 r.

\section{Rzeczywistość rozszerzona}

Rzeczywistość rozszerzona (ang. Augmented Reality) oznacza

(...) połączenie w czasie rzeczywistym prawdziwego świata, najczęściej w formie obrazu rejestrowanego przez obiektyw aparatu, z generowanym cyfrowo obrazem (Grabiec, 2013).

Możliwe jest też dołączenie obrazu i dźwięku lub tylko dźwięku. Zastosowanie tej technologii w muzeach pozwala na „oznakowanie” eksponatu wieloma informacjami dotyczącymi jego pochodzenia, historii, technologii wytworzenia itp. Korzystanie z rzeczywistości rozszerzonej jest możliwe za pomocą aplikacji na urządzenia mobilne lub za pośrednictwem znaczników umieszczonych przy eksponatach, np. kodów QR.

Rzeczywistość rozszerzoną można wykorzystać również poza murami muzeum, np. w przestrzeni miasta. Służą do tego specjalne okulary lub aplikacja na urządzeniu mobilnym, która po nakierowaniu urządzenia na dany obiekt pozwala zobaczyć np. jego dawniejszy wygląd.

Fot. 1. Rzeczywistość rozszerzona w aplikacji My Warsaw; źródło: http://www.pcworld.pl/news/383069/My.Warsaw.poznaj.Warszawe. Janusza.Korczaka.aplikacja.na.smartfony.html [dostęp 15.01.2016]

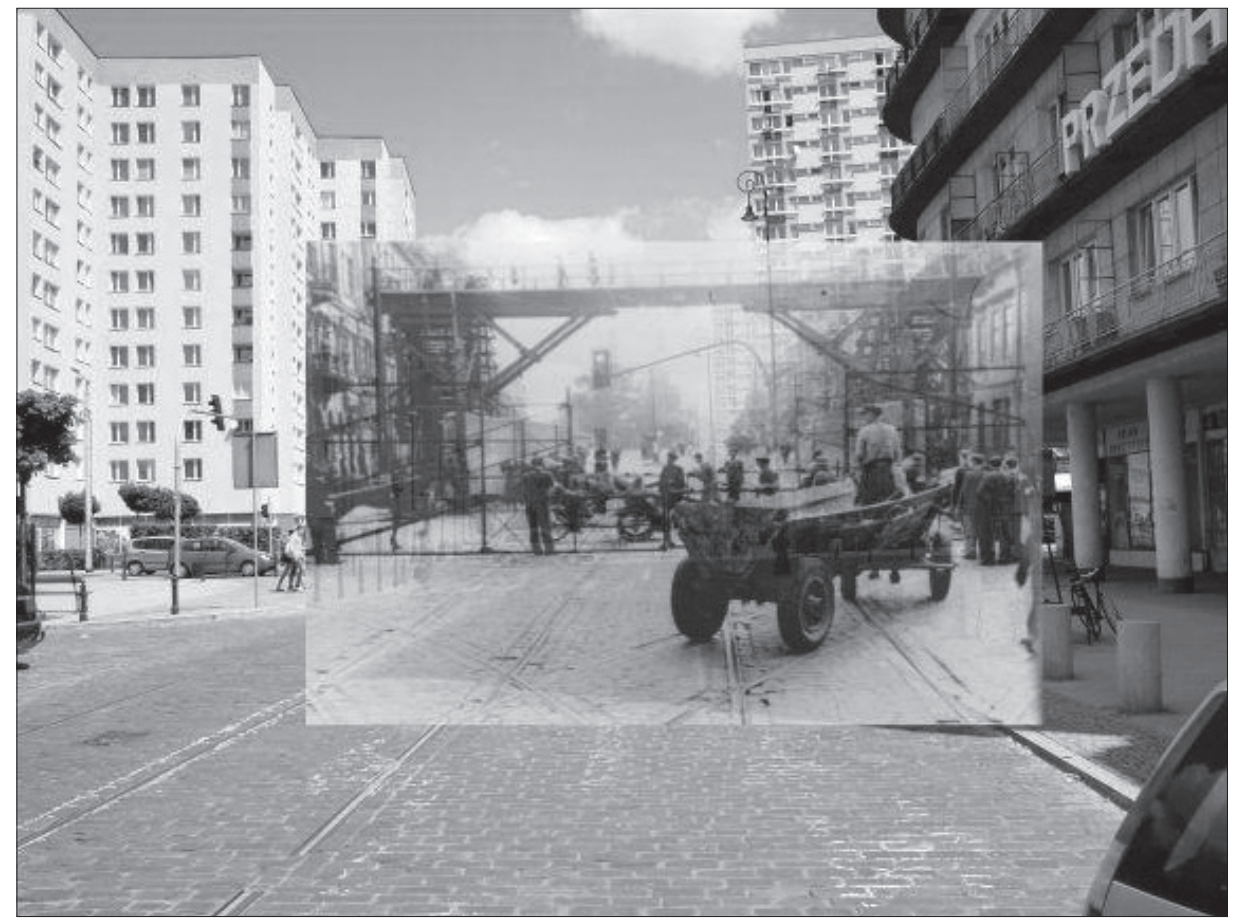


W muzealnictwie rozszerzona rzeczywistość ma największe możliwości pokazywania tego, czego nie da się przedstawić inaczej (bo np. już nie istnieje, albo jest za duże do przedstawienia). Technologię tę wykorzystuje się również do badań i prac nad rekonstrukcją znacznie uszkodzonych lub nieistniejących zabytków, gdyż pozwala ona na tworzenie dowolnych projektów i symulacji. W trosce o rzetelność prowadzonych rekonstrukcji w 2009 r. uchwalono Kartę Londyńską, która reguluje zasady używania rzeczywistości rozszerzonej w badaniach nad zabytkami (Karta Londyńska, 2009).

Rzeczywistość rozszerzona jest wykorzystywana w MPW w aplikacjach na urządzenia mobilne. Ponadto w 2013 r. na plenerowej wystawie „Głośniejsze od bomb”, dotyczącej historii powstańczych piosenek, przygotowanej dla Dzielnicy Mokotów, użyto QR kodów. Po ich zeskanowaniu urządzeniem mobilnym, możliwe było odsłuchanie piosenek powstańczych przyporządkowanych do poszczególnych kodów. Wystawa została umieszczona w plenerowej galerii Służewskiego Domu Kultury, była czynna w dniach od 30 lipca do 30 września $2013 \mathrm{r}$.

Na wystawie stałej w Muzeum POLIN nie wykorzystuje się możliwości, jakie daje rzeczywistość rozszerzona. Jest to konsekwencją przyjętego założenia, że widz ma skupić się na narracji wystawy, a nie rozpraszać się korzystaniem z dodatkowych urządzeń multimedialnych. Rzeczywistość rozszerzoną wykorzystuje natomiast oferowana przez POLIN aplikacja mobilna My Warsaw - Warszawa jest moja (patrz Fot. 1).

\section{Usługi wykorzystujące geolokalizację}

Geolokalizacja (Geographic Information System - GIS) umożliwia przypisanie każdemu obiektowi współrzędnych geograficznych. W muzealnictwie pozwala na tworzenie map i powiązanie zabytków z określonym miejscem wieloma relacjami (np. zabytek - miejsce wytworzenia, zabytek - miejsce przechowywania, zabytek - miejsce związane z jego tematyką lub twórcą). Wymaga to zapisania w metadanych zeskanowanego zabytku jego współrzędnych geograficznych, a także stworzenia słownika lokalizacji geograficznych (Mościcka \& Marzec, 2012).

W The 2010 Horizon Report: Museum Edition zwrócono uwagę na to, że zastosowanie geolokalizacji w przestrzeni muzeum pozwala na zaprezentowanie różnych treści dokładnie w tym miejscu, gdzie są one potrzebne i oczekiwane. Może tu chodzić o nowoczesne audioprzewodniki, ale oczywiście nie tylko one mogą być wyposażone w tę funkcję. Zwrócono też uwagę na przydatność geolokalizacji w informowaniu użytkownika o otoczeniu muzeum - parkingach, restauracjach, kawiarniach, innych instytucjach kultury, czy w ogólności o innych ciekawych miejscach w okolicy muzeum.

MPW posługuje się planami hipotecznymi miasta Warszawy z 1936 r. oraz fotoplanem z 1945 r., a także mapami Google w celu określenia lokalizacji obiektów udokumentowanych na zgromadzonych fotografiach. Dane lokalizacyjne wykorzystywane są następnie podczas tworzenia aplikacji na urządzenia mobilne.

Na wystawie stałej w Muzeum POLIN nie ma elementów odnoszących się do współrzędnych geograficznych. Geolokalizację wykorzystano natomiast z dużym powodzeniem w kilkuletnim (od czerwca 2014 do kwietnia 2016) projekcie pod nazwą Muzeum na kótkach. Jego ideą było dotarcie z informacją o żydowskiej przeszłości wielu miast i miasteczek do 
jej współczesnych mieszkańców. W tym celu wolontariusze wyjeżdżali specjalnie wyposażonym samochodem do miejscowości mających w swej historii związki z kulturą żydowską. Bardzo ważnym elementem wyposażenia tego samochodu był specjalny „stół” z ekranem, na którym dzięki wykorzystaniu systemu GIS wyświetlała się mapa miejscowości, w której zatrzymał się samochód-muzeum. Na mapie pojawiały się punkty interakcji (dotyczące danej miejscowości) oraz informacje o zabytkach żydowskich, zarówno tych istniejących nadal, jak i zupełnie zniszczonych i zapomnianych (Koch, 2015).

Obydwa omawiane muzea zastosowały geolokalizację, przedstawiając na swoich stronach internetowych interaktywną, skalowalną mapę Google, ukazującą usytuowanie muzeum w Warszawie oraz jego najbliższe otoczenie. Mapa mogła być wyświetlana w dwóch widokach: jako plan i jako zdjęcie satelitarne. Obecnie, w nowym serwisie MPW mapa ta jest niedostępna, natomiast w serwisie głównym Muzeum POLIN jest nadal dostępna i znajduje się w zakładce Zaplanuj wizytę/Dojazd do muzeum (http://www.polin.pl/pl/ zaplanuj-wizyte/dojazd-do-muzeum).

\section{Sieci semantyczne}

Sieci semantyczne stanowią podstawowe narzędzie wykorzystywane przez komputery w procesie łączenia wielu danych o obiektach. Technologia Sieci Semantycznej (Semantic Web) wykorzystuje dane i metadane obiektów, zapisane w formatach czytelnych maszynowo i dzięki językowi OWL (Web Ontology Language) stosuje wobec nich mechanizmy wnioskowania.

W praktyce muzealnej sieć semantyczną wykorzystuje się do łączenia obiektów znajdujących się w wielu różnych placówkach muzealnych. Beata Gontar (2013) wskazuje, że celem tworzenia oraz utrzymywania i rozwijania sieci semantycznej jest m.in.: umieszczenie w jednym repozytorium rozproszonych kolekcji, możliwość wyszukiwania informacji nie tylko za pomocą słów kluczowych, ale, co jest efektywniejsze, za pomocą pojęć wyodrębnionych i zakodowanych w specjalistycznych ontologiach oraz zapoznawanie użytkownika z powiązaniami semantycznymi między elementami wystawy, całymi kolekcjami tematycznymi oraz ich kontekstem.

W trakcie analizy technologii stosowanych w Muzeum Powstania Warszawskiego i Muzeum POLIN nie udało się jednak uzyskać informacji, czy muzea te wykorzystują w swojej pracy możliwości sieci semantycznych.

\section{Produkty cyfrowe}

\subsection{Elektroniczne gry edukacyjne}

Elektroniczna gra edukacyjna to produkt, który umożliwia zapoznawanie się z eksponatami muzealnymi przez zabawę. Obecnie renesans przeżywają gry planszowe. Elektroniczne gry edukacyjne są poniekąd odpowiedzią na tę modę. W znacznej części są one skierowane do najmłodszego pokolenia. Coraz więcej muzeów uwzględnia ten element w swojej ofercie.

Ani MPW ani muzeum POLIN nie ma w swojej ofercie elektronicznych gier edukacyjnych, choć obydwa muzea przymierzają się do realizacji takiego zadania. 


\subsection{Filmy 3D}

Film 3D to produkcja wytwarzająca iluzję głębi ruchomych obrazów. Uzyskuje się ją przez przygotowanie dwóch różnych obrazów z dwóch obiektywów (dla prawego i lewego oka). Skonstruowany w ten sposób obraz ogląda się przez specjalne okulary (Woś, 2013). Techniki stosowane przy uzyskiwaniu takiego efektu to obraz anaglificzny, naprzemienna sekwencja klatek lub technologia polaryzacyjna. Należy pamiętać, że technologia ta nie jest obojętna dla człowieka i u niektórych osób może wywoływać problemy z błędnikiem.

W 2010 r. na potrzeby MPW został wyprodukowany w technologii 3D film Miasto ruin. Film zrealizowała firma Platige Image. Reżyserem jest Damian Nenow. Jest to pierwsza w Polsce cyfrowa rekonstrukcja (na podstawie zdjęć) miasta zniszczonego w czasie II wojny światowej. Film trwa ponad 5 minut, symuluje lot „Liberatora” nad zniszczoną i wyludnioną Warszawą w 1945 r. Film jest odtwarzany w muzealnej sali kinowej.

Muzeum POLIN nie zrealizowało żadnego filmu w technologii 3D i w najbliższej przyszłości nie planuje takiego przedsięwzięcia.

\subsection{Telewizja cyfrowa (internetowa)}

Telewizja internetowa rozpoczęła swoją działalność w 2005 r. Za jej prekursora uważa się kanał YouTube. Obecnie istnieje wiele telewizji internetowych: od prowadzonych przez największe portale poprzez studenckie czy miejskie stacje telewizyjne, aż do telewizji tematycznych o różnym zasięgu. W środkach komunikacji miejskiej jest wykorzystywana telewizja internetowa, określana przez specjalistów od marketingu nazwą Digital Out-of-Home (cyfrowa komunikacja skierowana do konsumentów znajdujących się poza domem).

MPW nie prowadzi własnej stacji telewizji internetowej. Wyprodukowane przez siebie materiały audiowizualne zamieszcza na kanale YouTube, do którego link znajduje się na stronie głównej placówki. Oficjalny kanał MPW na YouTube w lutym 2016 r. zawierał 481 filmów (stan na 13 lutego 2016 r.); obecnie liczba ta wzrosła do 548 filmów (stan na 18 stycznia 2017 r.). Jednak filmów związanych z muzeum jest wielokrotnie więcej - obecnie (styczeń 2017 r.) około 14.5 tys. Użytkownicy tego kanału w komentarzach zwracają uwagę, że brakuje kategoryzacji zamieszczanych treści, co bardzo utrudnia wyszukiwanie. Muzeum korzysta też z usług telewizji cityINFOtv, wyświetlającej treści na ekranach umieszczonych w środkach komunikacji miejskiej. Z uwagi na specyfikę tego medium spoty tam zamieszczane są bardzo krótkie. Co roku przez ponad dwa miesiące, w dniach od 1 sierpnia do 2 października prezentowane są „kartki z kalendarza”, przypominające najważniejsze wydarzenia z danego dnia powstania. Przed rocznicą wybuchu Powstania emitowane są spoty przypominające o uczczeniu godziny „W” minutą ciszy i bezruchu.

Muzeum POLIN również nie posiada własnego kanału telewizji. Do zamieszczania filmów wykorzystuje kanał YouTube, do którego link jest zamieszczony na stronie głównej placówki. Oficjalny kanał Muzeum POLIN na YouTube w lutym 2016 r. zawierał 261 filmów (stan na 27 lutego 2016 r.), a obecnie już 433 filmy (stan na 18 stycznia 2017 r.). Podobnie jak w przypadku MPW, również filmów związanych z muzeum POLIN jest wielokrotnie więcej - obecnie (styczeń 2017 r.) około 3220. Muzeum co jakiś czas przygotowuje spoty przeznaczone do emisji w telewizji w środkach komunikacji miejskiej. Emitowane są one dla przypomnienia o rocznicy wybuchu powstania w getcie lub w celu poinformowania o nowych inicjatywach placówki. 


\section{Zarządzanie muzeum i udostępnianie jego usług online}

Do zarządzania współczesnym muzeum potrzebne są nowoczesne programy komputerowe, wspomagające zarówno katalogowanie i udostępnianie zbiorów muzealnych, jak i umożliwiające planowanie zadań placówki (zob. np. Batko \& Kotowski, 2010; Folga-Januszewska, 2008) . Obecnie na rynku jest dostępnych wiele programów komputerowych, ułatwiających zarządzanie firmami i placówkami usługowymi. Biorąc pod uwagę specyfikę pracy w muzeach, programy te można podzielić na dwie główne kategorie: służące do zarządzania muzealiami (np. dMuseion, MONA, MUSNET) oraz służące do udostępniania usług muzealnych online i zarządzania placówką muzealną - tu warte podkreślenia jest zainteresowanie muzeów systemami CRM (Customer Relationship Management), wykorzystywanymi dotychczas w biznesie.

dMuseion jest kompleksowym oprogramowaniem służącym do tworzenia muzeów cyfrowych, udostępnianych w Internecie. Jego twórcą jest Poznańskie Centrum Superkomputerowo-Sieciowe. Program powstał w 2009 r. na bazie systemu dLibra. Umożliwia on prezentację zabytków w formie miniatur dwu- i trzywymiarowych (tzw. technologia 3D). Oprogramowanie pozwala m.in. na tworzenie hierarchicznej struktury przechowywania zabytków, tworzenie katalogów zabytków na podstawie systemu inwentaryzacji zabytków np. MONA, import metadanych zabytków oraz integrację z innymi systemami informacyjnymi (posiada zgodność z protokołem OAI-PMH, co ułatwia udostępnianie zbiorów cyfrowych danej placówki w Europeanie) (Czyż \& Romeyko-Hurko, 2010).

MPW posiada elektroniczny katalog muzealiów MUSNET. Sprawdza się on dobrze jako system do inwentaryzacji i opracowywania zbiorów, ale niekoniecznie do udostępniania zbiorów online - nie posiada możliwości tworzenia wirtualnych wystaw i prezentacji zbiorów. Okazało się też, że brak jest komunikacji MUSNET z muzealną stroną internetową. Z tego powodu MPW zdecydowało się zamówić rozszerzenie tego programu o nowe funkcje. MPW wykorzystuje, jak wiele innych placówek kultury, programy wspomagające działanie placówki w zakresie finansów i kadr. Pod koniec 2015 r. muzeum było w fazie projektowania systemu CRM do zarządzania wolontariuszami.

Na stronie MPW do czasu jej zmiany można było znaleźć wszystkie informacje ważne dla zwiedzających, zakupić bilet na zwiedzanie ekspozycji, zamówić przewodnika oprowadzającego po ekspozycji, zarezerwować lekcję muzealną, pobrać scenariusze lekcji do przeprowadzenia w szkole (przedszkolu), a także pobrać inne materiały. Była też możliwość elektronicznego zamówienia publikacji ze zbiorów muzeum do skorzystania w muzealnej czytelni, gdyż na stronie internetowej muzeum znajdował się katalog zbiorów (http://www.1944.pl/edukacja_i_kultura/czytelnia/katalog/). Kolejną funkcją oferowaną na stronie internetowej był e-sklep (http://www.muzeum1944.home.pl/sklepik_mpw), w którym można było nabyć wydawnictwa, płyty i pamiątki. Obecna wersja serwisu jest pod tym względem znacznie uboższa - poza informacjami dla zwiedzających i sklepem internetowym, oferuje jedynie dokonanie rezerwacji biletów na zwiedzanie ekspozycji oraz zgłoszenie rezerwacji lekcji muzealnej.

Muzeum POLIN posiada i wykorzystuje program komputerowy do zarządzania muzealiami, jednak z uwagi na ochronę swoich interesów nie udziela informacji na jego temat. Wiadomo jedynie, że Centralna Baza Judaików została zbudowana na bazie programu dMuseion. Muzeum wykorzystuje programy komputerowe do zarządzania placówką. 
Są to m.in. programy kadrowe i finansowe. Pracownicy korzystają z wewnętrznej poczty elektronicznej. W 2016 r. muzeum wdrożyło program pod nazwą „Kalendarz wydarzeń”, opracowany przez firmę INTRATIC, zastępując tym produktem starszy program, który nie spełniał wymagań pracowników. Nowe rozwiązanie zapewnia dodawanie wydarzeń do zestawienia, rezerwację zasobów na dane wydarzenie, a także sporządzanie raportów i podsumowań z każdego wydarzenia. „Kalendarz wydarzeń” składa się z aplikacji dla pracowników, która może być obsługiwana zdalnie, oraz z konsoli administracyjnej, pozwalającej na konfigurację uprawnień użytkowników i zawierającej bazę danych (Intratic, 2016).

Na stronie Muzeum POLIN, w zakładce Zaplanuj wizytę, można znaleźć wszystkie informacje ważne dla zwiedzających. Za pośrednictwem strony internetowej można kupić bilet na zwiedzanie ekspozycji, zarezerwować lekcję muzealną, zgłosić grupowe zwiedzanie ekspozycji. Dostępna jest też rozbudowana Baza materiałów dydaktycznych, z której można pobrać biuletyn dla nauczycieli, scenariusze lekcji do przeprowadzenia w szkole (przedszkolu) oraz prezentacje i materiały źródłowe do tych lekcji. Na stronie internetowej muzeum znajduje się e-sklep (http://store.jewishmuseum.org.pl/), oferujący książki, katalogi wystaw muzealnych, pamiątki oraz wiele innych produktów związanych z kulturą żydowską.

\section{Wyzwania i trudności związane z wdrażaniem nowych technologii w muzeach}

The 2010 Horizon Report: Museum Edition ukazuje wyzwania i ograniczenia, przed którymi stają muzea wdrażające techniki cyfrowe. Wśród nich wymieniane są: niewystarczające przygotowanie pracowników muzeów do wykorzystywania cyfrowych narzędzi tworzenia i udostępniania ekspozycji muzealnych, brak środków finansowych do realizacji projektów, trudności techniczne wynikające z nieprzystosowania starych budynków muzealnych do zainstalowania w nich ogromnej liczby przewodów elektrycznych koniecznych do działania multimediów (rozwiązaniem w takich przypadkach mogą być technologie bezprzewodowe), brak całościowych strategii cyfrowych, brak zrozumienia dla coraz większych oczekiwań poznawczych i edukacyjnych osób odwiedzających muzea, brak praktyki wśród edukatorów muzealnych w posługiwaniu się nowoczesnymi urządzeniami cyfrowymi oraz, co znacznie ważniejsze, brak umiejętności poruszania się w środowisku informacji dostępnej online z wielu źródeł jednocześnie.

Z wywiadów przeprowadzonych z pracownikami MPW i Muzeum POLIN nie wynika, aby wymienione $\mathrm{w}$ raporcie trudności były decydujące $\mathrm{w}$ ich pracy. Oczywiście zawsze można (i robi się to) wskazać na zbyt szczupłe zasoby finansowe.

Trudności techniczne związane z okablowaniem budynków muzealnych w omawianych przypadkach nie występują, gdyż budynek MPW przeszedł gruntowny remont przed umieszczeniem w nim ekspozycji, a budynek Muzeum POLIN był projektowany z myślą o wystawie bogatej w multimedia.

Stałe digitalizowanie zasobów muzealnych obu placówek (w MPW wykonywane na bieżąco) i zamieszczanie w ich serwisach internetowych różnych wystaw wirtualnych wskazuje na to, iż placówki te mają wypracowane strategie cyfrowe i konsekwentnie je realizują. Widoczne jest to również w decyzjach o nieudostępnianiu wszystkich zasobów $\mathrm{w}$ formie cyfrowej. 
Obserwując zaangażowanie i poziom wiedzy pracowników obu muzeów, nie można im zarzucić braku praktyki czy umiejętności w poruszaniu się w środowisku cyfrowym i korzystaniu z nowoczesnych urządzeń elektronicznych.

\section{Wnioski}

Przedstawiona powyżej analiza różnych aspektów wykorzystywania technologii cyfrowej w Muzeum Powstania Warszawskiego i w Muzeum Historii Żydów Polskich POLIN prowadzi do następujących obserwacji:

- oba muzea z powodzeniem przeprowadziły i prowadzą nadal digitalizację swoich zbiorów, a cyfrowe kopie zabytków udostępniają w różnych formach w Internecie;

- formy prezentacji zabytków w Internecie są stale udoskonalane, o czym świadczy obecnie trwająca przebudowa serwisu MPW, prezentacja wirtualnych wystaw kolejno na różnych portalach związanych z Muzeum POLIN, a także wprowadzenie nowego portalu związanego z tym muzeum;

- muzea celowo nie dążą do pełnego przeniesienia swoich zasobów do Internetu, świadomie pozostawiając u użytkownika tego medium pewien niedosyt, który może zostać zaspokojony podczas wizyty w muzeum.

Powyższe stwierdzenia pozwalają na sformułowanie generalnego wniosku, że oba muzea, które poddano analizie, w sposób przemyślany i skuteczny stosują technologię cyfrową w swej działalności.

Należy jednak sformułować i drugi wniosek, mówiący, że proces wdrażania do praktyki muzealnej kolejnych rozwiązań technologii cyfrowej daleki jest od zakończenia (a biorąc pod uwagę dynamikę rozwoju tej technologii, być może nie zakończy się nigdy). W chwili powstawania niniejszego opracowania stwierdzono, iż:

- dwa najbardziej znane z innowacyjnej działalności muzea nie wykorzystują możliwości, jakie dają elektroniczne gry edukacyjne - wydaje się, że w obliczu współczesnych form spędzania wolnego czasu przez dzieci i młodzież, jest to znaczący brak w działalności edukacyjnej tych placówek;

- coraz wyższe standardy działań edukacyjnych zapewne wymuszą na muzeach zastosowanie w pewnym momencie spersonalizowanych audioprzewodników, dostosowanych do wieku i zainteresowań odbiorcy;

- poddane analizie muzea nie wykorzystują wszystkich elementów technologii cyfrowej, wskazanych w The 2010 Horizon Report: Museum Edition - nie stwierdzono zastosowania sieci semantycznej, komputeryzacja oparta na geście nie wykorzystuje najnowszej technologii odczytu gestów przez kamery sprzężone z komputerami, warto też poszerzać wachlarz rozwiązań wykorzystujących geolokalizację oraz rozważyć wprowadzenie wersji mobilnej głównych portali internetowych obu muzeów;

- technologia cyfrowa nie tylko umożliwia dostosowanie form ekspozycji i przekazu wiedzy do oczekiwań młodego pokolenia, ale również w istotny sposób może ułatwić dostęp do zbiorów muzealnych osobom starszym i niepełnosprawnym. Otwartym pozostaje pytanie, na ile skierowanie technologii cyfrowej w muzealnictwie do tych właśnie osób stanie się rzeczywiście zauważalnym trendem i faktyczną dla nich pomocą w kontakcie z historią, kulturą i sztuką, a na ile pozostanie marginesem działań muzeów. 
Polscy muzealnicy są zainteresowani rozwojem muzeów i udoskonalaniem ich oferty naukowej, edukacyjnej i rozrywkowej. Zauważają problemy i starają się je rozwiązywać. Dowodem na to są m.in. konferencje poświęcone różnym aspektom działania muzeów. Już po złożeniu artykułu, ale jeszcze przed jego publikacją, w dniach 7-8 grudnia 2016 r., odbyła się w Muzeum Powstania Warszawskiego konferencja „Muzeum i zmiana. Czasy muzeów narracyjnych" (http://www.1944.pl/artykul/konferencja-muzeum-i-zmiana.-czasy-muzeow-na,4594.html), poruszająca zagadnienia związane z boom'em muzealnym w Polsce, przyjmowaniem w muzeum różnych odbiorców (osoby starsze, rodziny z dziećmi, uczniowie), wpływem muzeów narracyjnych na postrzeganie historii oraz sposobem funkcjonowania muzeów. MPW zapowiedziało, że materiał pokonferencyjny w formie filmów zamieści na swoim oficjalnym kanale na YouTube.

\section{Bibliografia}

Barycki, P. (2014). Tam, gdzie nowe taczy się ze starym, czyli geek idzie do muzeum [online] Spider'sWeb [19.03.2015], http://www.spidersweb.pl/2014/02/nowoczesne-technologie-w-muzeachw-polsce-na-swiecie.html

Batko, R.; Kotowski, R. (2010). Nowoczesne muzeum: dziedzictwo i wspótczesność. Kielce: Muzeum Narodowe.

Britisch Council (2014). Polka rozwija nowe technologie w kulturze [online]. Britisch Council [20.03.2015], http://www.britishcouncil.pl/about/press/polka-rozwija-nowe-technologie-w-kulturze

Czyż, P.P.; Romeyko-Hurko, M. (2010). dMuseion: od bazy danych do muzeum cyfrowego. W: C. Mazurek; M. Stroiński; J. Węglarz (red.). Polskie Biblioteki Cyfrowe 2009. Materiaty z konferencji. Poznań: Ośrodek Wydawnictw Naukowych, 21-29.

Duranti, L. (2012). Zaufanie oraz kolidujące ze sobą prawa w środowisku cyfrowym. W: Archeion, t. CXIII, 25-35.

Folga-Januszewska, D. (2008). Muzea w Polsce 1989-2008 [online]. Kongres Kultury Polskiej [12.05.2015], http://www.kongreskultury.pl/library/File/RaportMuzea/muzea_raport_w.pelna(1).pdf Gaweł, Ł. (2012). Bez kompasu i bez mapy. O zarządzaniu digitalizacją zbiorów muzealnych w Polsce. Muzealnictwo, 53, 120-123, http://muzealnictworocznik.com/abstracted.php?level=5\&I$\mathrm{CID}=1086189$

Gontar, B. (2013). Cyfrowa rewolucja w muzeach. [online] [20.03.2015], https://www.ur.edu.pl/ file/53264/11.pdf.

Grabiec, P. (2013). Rzeczywistość rozszerzona - z czym się to je? [online]. Spider'sWeb [22.04.2015], http://www.spidersweb.pl/2013/10/rzeczywistosc-rozszerzona-qualcomm.html

Intratic (2016). Kalendarz wydarzeń dla Muzeum Historii Żydów Polskich POLIN - case study [online]. INTRATIC [15.01.2016], http://www.intratic.eu/pl/kalendarz-wydarzen-dla-muzeumhistorii-zydow-polskich-polin-case-study/

Jakubowski, K. J. (2010). Muzea wobec dylematów rozwojowych społeczeństwa wiedzy. W: Muzeum XXI wieku - teoria i praxis. Materiaty z sesji naukowej, organizowanej przez Muzeum Poczatków Państwa Polskiego i Polski Komitet Narodowy ICOM, Gniezno, 25-27 listopada 2009 roku. Gniezno: Muzeum Początków Państwa Polskiego, 36-46.

Kamińska, E. (red.). (2014). Prawne aspekty digitalizacji i udostępniania danych muzealnych przez Internet [online]. Narodowy Instytut Muzealnictwa i Ochrony Zbiorów [13.01.2017], http:// digitalizacja.nimoz.pl/uploads/zalaczniki/Prawne_aspekty_digitalizacji_i_udostepniania_NIMOZ_2014.pdf

Karta Londyńska (2009). Karta Londyńska. Zasady dotyczace komputerowych metod wizualizacji dziedzictwa kulturowego [online]. Uniwersytet Wrocławski - Wydział Nauk Historycznych 
i Pedagogicznych - Instytut Historii Sztuki [4.05.2015], http://www.historiasztuki.uni.wroc.pl/ projekty_badawcze/doc/kart_londynska_PL.pdf.

Kłos, M.; Nowacka, A. (2011). Dobre praktyki digitalizacji na podstawie doświadczeń Międzymuzealnej Grupy ds. Digitalizacji DigiMuz. Muzealnictwo, 52, 61-72, http://muzealnictworocznik. com/abstracted.php?level=5\&ICID $=1088175$

Koch, Ł. (2015). Muzeum na kółkach. W: Materiały XXII seminarium w cyklu „Nowoczesne muzea i galerie" - Muzeum narracyjne - media i metody budowania opowieści, Warszawa 1 kwietnia 2015. Warszawa: CPI, 97-100.

Kozieł, K. (2013). Strona mobilna czy responsywna? Oto jest dylemat! [online]. Enzo [5.03.2016], http://enzo.pl/2013/06/26/strona-mobilna-czy-responsywna-oto-jest-dylemat/

Lehenstein-Werndl, M. (2007). Elementy, które wptywaja na intuicyjność i ergonomię strony internetowej [online]. eioba [19.11.2015], http://www.eioba.pl/a/1jbb/elementy-ktore-wplywaja-naintuicyjnosc-i-ergonomie-strony-internetowej

Marzec, Ł.; Krynicki, M. (2015). „Ta sama przestrzeń - wiele opowieści”. Audioprzewodnik jako narzędzie budowania narracji. W: Materiaty XXII seminarium w cyklu „Nowoczesne muzea i galerie”- Muzeum narracyjne - media i metody budowania opowieści, Warszawa 1 kwietnia 2015. Warszawa: CPI, 61-68.

Mościcka, A.; Marzec, M. (2012). Rola informacji geograficznej w opisach dóbr kultury w ułatwianiu dostępu do zasobów dziedzictwa. W: E. Herden; A. Seidel-Grzesińska; K. Stanicka-Brzezicka (red.). Dobra kultury w Sieci. Wrocław: Wydaw. Uniwersytetu Wrocławskiego, 149-157.

Pawłowska, A.; Matoga, Ł. (2014). Wirtualne muzea w Internecie - forma promocji i udostępniania dziedzictwa kulturowego czy nowy walor turystyczny? Turystyka Kulturowa [online], 9 [20.03.2015], http://turystykakulturowa.org/ojs/index.php/tk/article/viewFile/495/463

Raport (2010). The Horizon Report 2010 Museum Edition [online]. New Media Consortium [5.03.2016], http://www.nmc.org/pdf/2010-Horizon-Report-Museum.pdf

Raport (2016). Raport „Muzea w Polsce” [online]. Narodowy Instytut Muzealnictwa i Ochrony Zbiorów [14.01.2017], http://nimoz.pl/pl/dzialalnosc/statystyka-muzeow-2/raport-muzea-w-polsce

Rosenfeld, L.; Morville, P. (2003). Architektura informacji w serwisach internetowych, Gliwice: Helion.

Skórzyńska, I. (2014). Muzeum historyczne: teatr - widowisko, aktor - świadek. W: R. Kostro; K. Wóycicki; M. Wysocki (red.). Historia Polski od-nowa: nowe narracje historii i muzealne reprezentacje przeszłości. Warszawa: Muzeum Historii Polski, 88-107.

Stefanik, M.; Kamel, M. (2013). Muzea i wystawy interaktywne w Polsce - wspótczesna atrakcja turystyczna. Turystyka Kulturowa [online], 8, [21.03.2015], http://www.turystykakulturowa.org/ pdf/2013_08_01.pdf

Woś, A. (2013). Co to jest kino 3D, 4D albo nawet 5D? [online]. CafeSenior [21.04.2015], http:// cafesenior.pl/co-to-jest-kino-3d-4d-albo-nawet-5d/.

Wp.pl (2015). Strona o Powstaniu Warszawskim wyróżniona najważniejsza nagroda internetu [online]. Wiadomości WP [24.11.2015], http://wiadomosci.wp.pl/kat,1019393,title,Strona-o-Powstaniu-Warszawskim-wyrozniona-najwazniejsza-nagroda-internetu,wid,17491897,wiadomosc. html?ticaid $=116000$

Zachara, T. (2014). Cyfrowy eksponat. Możliwości prezentacji obiektów muzealnych w sieci na przyktadzie Muzeum Historycznego w Legionowie. Praca licencjacka napisana pod kierunkiem dr. Grzegorza Gmiterka w Instytucie Informacji Naukowej i Studiów Bibliologicznych na Wydziale Historycznym Uniwersytetu Warszawskiego [dok. niepubl.].

Zachara, T. (2016). Technologia cyfrowa $w$ muzealnictwie: na przykładzie wybranych muzeów historycznych w Warszawie. Praca magisterska napisana pod kierunkiem prof. Barbary Sosińskiej-Kalaty w Instytucie Informacji Naukowej i Studiów Bibliologicznych na Wydziale Historycznym Uniwersytetu Warszawskiego [dok. niepubl.].

Żywek, Ł. (2015). Internetowe katalogi zbiorów w muzeach polskich. Niepodlegtość i Pamiecć, 3(51), 241-272. 


\title{
Digital Technology in the Narrative Museums on the Example of the Warsaw Rising Museum and POLIN Museum of the History of Polish Jews
}

\begin{abstract}
Purpose/Thesis: The paper presents the results of the research aimed at determining the scope and methods of digital technology use by two well-known Polish narrative museums: the Museum of the Warsaw Rising (MPW) and POLIN Museum of the History of Polish Jews (POLIN Museum). Approach/Methods: In the presented study three methods were used: the analysis of the sources that provided some insight into the changing role of museums and their use of digital technologies; the local observations and interviews with the staff in the Warsaw Rising Museum and POLIN Museum of the History of Polish Jews, that allowed to get oneself acquainted with the digital technologies employed in those museums; the analysis of the websites of the two museums in question. The triangulation of these methods enabled a systematic review of the use of various tools and methods of digital technology within the range of areas and forms of activity of the selected museums.

Results and conclusions: The study revealed that the implementation of digital technology in museums is a long process and far from being completed, for instance, due to constantly emerging new technologies. Polish museums do not use all possibilities offered by the digital technology, but due to the increasing visitors' demands they will probably be forced to implement the most recent solutions. Originality/Value: The paper presents nine areas of museum activity where the digital technologies can be applied. It is a brief compendium of information on this area of knowledge and practice, illustrated with examples of applications of a specific technology or devices in the two museums.
\end{abstract}

Keywords

Applications for mobile devices. Augmented reality. Digital technology. Modern museum exhibitions. POLIN Museum of the History of Polish Jews. Semantic networks. Social networking sites. Warsaw Rising Museum.

Mgr TERESA ZACHARA jest absolwentka Instytutu Informacji Naukowej i Studiów Bibliologicznych. Pracuje jako starszy specjalista w Departamencie Dziedzictwa Kulturowego za Granica i Strat Wojennych Ministerstwa Kultury i Dziedzictwa Narodowego. Jest autorką artykutów w biuletynie Przeszłość i Pamięć oraz trzeciego tomu publikacji Powstanie styczniowe. Mogity i miejsca pamięci (Rada Ochrony Pamięci Walk i Męczeństwa, 2013). Interesuje się wprowadzeniem nowoczesnych technologii cyfrowych w placówkach zajmujacych się historia.

Kontakt $z$ autorka:

tzachara@mkidn.gov.pl

Departament Dziedzictwa Kulturowego za Granica i Strat Wojennych

Ministerstwo Kultury i Dziedzictwa Narodowego

ul. Krakowskie Przedmieście 15/17

00-071 Warszawa 